\title{
Research Comparing University Teaching within the EHEA between the University CEU Cardenal Herrera in Spain and the University of Bedfordshire in England
}

\author{
Asunción Romero López ${ }^{1}$, Helena María Pascual Ochando², María Fernández Cabezas ${ }^{3}$ \\ ${ }^{1}$ Dpto. Didáctica y Organización Escolar, University of Granada, Granada, Spain \\ ${ }^{2}$ Dpto. de Educación, CEU Cardinal Herrera University, Valencia, Spain \\ ${ }^{3}$ Dpto. Psicología educativa y de la Educación, University of Granada, Granada, Spain \\ Email: hpascual@ugr.es
}

Received 5 October 2015; accepted 17 November 2015; published 20 November 2015

Copyright (C) 2015 by authors and Scientific Research Publishing Inc.

This work is licensed under the Creative Commons Attribution International License (CC BY).

http://creativecommons.org/licenses/by/4.0/

(c) (i) Open Access

\begin{abstract}
Teaching methodologies that university faculty use are varied but in Spain, traditionally, the lecture has been the main method used. This is where the teacher has been the focus of teaching and the student is a mere receiver of knowledge, but in other places such as England, other techniques have been introduced to help students actively participate, helping the learning process significantly. This has been a great help for adaptation to the European Higher Education Area with the implementation of the Bologna Process. That is why countries with long traditions of theoretical teaching, as is the case in Spain, have undergone a complex and traumatic process during the adaptation period. In Spain there has been a change of roles by both the faculty as well as the students and that has led to some mistakes when implementing new working tools such as seminars and workshops. The research presented makes a comparison between the faculty teaching in the Primary School Teaching Degrees at two universities; one Spanish and one English, for the Bologna process to check the similarities and differences when working and thereby obtain information needed to improve the process in Spain.
\end{abstract}

\section{Keywords}

European Higher Education Area, Methodology, University Teaching

\section{Introduction}

In Spain the universities have been charged with a great responsibility to address vital issues such as culture,

How to cite this paper: López, A.R., Ochando, H.M.P. and Cabezas, M.F. (2015) Research Comparing University Teaching within the EHEA between the University CEU Cardenal Herrera in Spain and the University of Bedfordshire in England. Open Journal of Social Sciences, 3, 250-261. http://dx.doi.org/10.4236/jss.2015.311030 
economy, and social development. This important role that the university holds is affected by social and political changes even though article 27.10 of the 1978 Constitution gives autonomy to universities. This has been used by the Spanish universities to follow specific criteria focusing on the culture and history of each which have been highly traditional.

As the years passed and to improve the quality of teaching, research and management, a renewed legal framework was developed in Spain with the LRU (Organic Law 11/83, 25 August (BOE No. 209 September 1, 1983)). The LRU states that the university is the best social organization to undertake the development of scientific and technical advancement required for the incorporation of Spain to developed and advanced industrial societies. This law tried to offer a new university system that reached the quality of teaching and research required, as well as establishing a framework for the renewal of academic life, while respecting universities' autonomy.

With this reform the common guidelines of the curricula of university degrees throughout the country were established, and were aimed at redefining the new training and academic demands.

One of the most significant changes for the Spanish universities was the computation of credits in Organic Law 6/2001 of 21 December on Universities (LOU from here forward). Although the LRU already defined a credit as "a unit of teaching evaluation", corresponding to ten hours of theoretical or practical teaching, or their equivalent. To obtain these credits was conditional on verification systems of knowledge established by the universities (art. 2.7 RD 1497/1987). Among all these changes the Sorbonne Declaration of 1998 was made, which launched the European Higher Education Area, forcing the Spanish government to initiate a process of adaptation of higher education with EU requirements to unify university education systems and thus achieve the free movement of students, future recognition of qualifications and thereby the free labor market.

The European Higher Education Area is a new concept of university education, from which Europe wants to standardize degrees. However, this system is closer to some member states, such as the northern European members, whose educational content and methodologies are more in line with this process and are therefore better suited than those of the Mediterranean countries with a greater theoretical tradition. Blández (2006) [1] and Pello (2005) [2] warn that the creation of the European Higher Education Area is one of the biggest challenges faced by Spain and Europe and that, in some ways, it is the means that will lead to the complete unification of Europe both in the educational and training level as well as economically, achieving a free and open market access.

The process which Europe has passed and, as a consequence, Spain, has been long and hard. It has caused many changes in how people work and the system of teaching and learning operates.

The origin of the European Higher Education Area (EHEA) is the Magna Carta of European universities, which began from France, Germany, Italy and the United Kingdom meeting in Bologna on September 18th, 1988. In it, the University Rectors of these countries took the decision to unify the cultural, scientific and technical development and the importance of conveying knowledge to the general public, ensuring future generations an education that allows them to contribute to the social and natural environment. With the first agreements the unifying of ideas and countries begins (Garcia and Blanco, 2007) [3].

With this beginning the entire system started moving, holding meetings and publishing documents, to outline this idea of cultural, educational and employment unification in Europe. In 1997, with the Lisbon Declaration (Lisbon Recognition Convention), understood as the recognition of university qualifications and access to undergraduate and graduate degrees, the objective of unifying undergraduate degrees and the creation of graduate degrees is met. This allows students to begin an undergraduate or graduate degree in one country and continue, or finalize, in another as they will have the same credits and weight.

In 1998 thanks to the Sorbonne Declaration, this project becomes a reality by signing the Magna Charter, although for Vázquez (2005) [4], the true benchmark of the EHEA is the Bologna Declaration (1999). With this declaration the jump from an idea to a firm commitment to achieve this project, is accomplished. With it comes the adoption of a system of easily readable and comparable degrees, through the introduction of the Diploma Supplement, adopting a system essentially based on two main cycles, respectively of first and second level in all European university systems, or establish a system of credits equal for all Europe, called ECTS, to promote student mobility.

For all the proposals developed in the Bologna Declaration, it was decided that a series of meetings were to be held every two years to follow up on the progress and work being achieved. These meetings took place respectively in Prague (2001), Berlin (2003), Bergen (2005), London (2007), Louvain-la-Neuve (2009), BudapestVienna (2010) and Bucharest (2012). The last of these having taken place in 2015 in Yerevan. In each of the 
meetings, progress was made in the advancement of the future of the EHEA.

All these meetings and agreements have served to consolidate the idea of a common area that recognizes everyone equally and that helps the working future of young Europeans. Despite regulations and agreements, the process within universities and schools has been more difficult than expected, as it has meant a change in the mindset of teachers and students. (Bain 2006) [5] (Table 1).

\section{Change in the Teaching-Learning Process}

One of the biggest challenges for the EHEA has been the methodology, especially for countries with a long tradition of theoretical teaching. In the specific case of Spain, it has shown that the adaptation has been much more complex and traumatic as it is one of the countries whose system is farthest away from the new methods, requiring more effort and work to be done. (Vázquez, 2005) [4].

The characteristics of the Spanish university system hinder the integration in the new higher education system. To better understand the problems with the adaptation we have to look at the most significant characteristics::

- The Spanish university system historically has had many changes and often unnecessarily, which makes us more skeptical and more intolerant of change (Valle, 2006) [6].

- The low development of foreign language learning by most students and faculty, which does not help with mobility within Europe (García and Blanco, 2007) [3].

- Overcrowding of Spanish universities, where the number of pupils is excessive makes it very difficult to implement new methodologies (Molero, 2007) [7].

These difficulties are not the only obstacles afflicting our system since the university faculty has had to change their role and the way they work without obtaining prior training. Even though they are skilled and know how to teach and transmit their knowledge, their professional profile does not meet the requirements of Europe because the Bologna Process aims to put the spotlight on the students and their participation, focusing on skill training and access to the labor market. As Noguera (2004) [8] states, this is a disadvantage compared to European countries that have faced the issue of professionalization of university faculty functions with more vigor and resources. In Spain, faculty training is done individually and on a voluntary basis. There are almost no incentives for teachers who gain further training and no structure which indicates what training courses should be undertaken to face the coming changes.

Table 1. Meetings and objectives carried out throughout the process.

\begin{tabular}{|c|c|c|}
\hline Year & Meetings & Objectives \\
\hline 2001 & Prague & $\begin{array}{l}\text { Set up the European Higher Education Area by } 2010 . \\
\text { Life Long Learning }\end{array}$ \\
\hline 2003 & Berlin & Strengthen the idea that higher education is a public benefit and responsibility \\
\hline 2005 & Bergen & $\begin{array}{l}\text { Ensure that the general framework of qualifications of the EHEA and lifelong learning are complementary. } \\
\text { Promote the importance of the mobility of students and academic staff. }\end{array}$ \\
\hline 2007 & London & Encouraging a significant increase in the number of joint programs and the creation of flexible curricula. \\
\hline 2009 & Louvain-la- Neuve & The objective is that the lessons are applied and self-certified by 2012 for the EHEA. \\
\hline 2010 & Budapest-Vienna & $\begin{array}{l}\text { Enhance academic freedom as well as autonomy accountability of higher education institutions. } \\
\text { To understand that higher education is a public responsibility. } \\
\text { Establish equal opportunities. }\end{array}$ \\
\hline 2012 & Bucharest & $\begin{array}{l}\text { Provide high-quality education for all. } \\
\text { Enhance graduates' employability. } \\
\text { Strengthening mobility for improved learning. }\end{array}$ \\
\hline 2015 & Yerevan & $\begin{array}{l}\text { Include short cycle qualifications with the framework of qualifications for the European Higher } \\
\text { Education Area (QF-EHEA). } \\
\text { Review of national legislation in order to comply fully with the recognition of the Convention of Lisbon. } \\
\text { Establish a group of voluntary organizations and countries to facilitate professional recognition. } \\
\text { Ensure qualifications are automatically recognized by other EHEA countries at the same level as } \\
\text { relevant domestic qualifications. }\end{array}$ \\
\hline
\end{tabular}


The model most used by Spanish faculty until now was based on behavioral learning theory, the lecture has been, or in some cases still is, the teaching method used by teachers and the student is a mere passive recipient. This model helps develop the learning of cognitive skills and memory capacity but fails to develop other skills and abilities that students need for their future careers, such as with the autonomous development, teamwork, development and research inquiry...etc.

For Mayer (1992) [9], the teacher's role is to create environments where the student is instructed, repetitively if need be, to give a simple answer, which is immediately followed by a response (feedback) and by this create another response and thus a debate and a student's own thinking. This can occur in a lecture workshop or seminar.

De Miguel (2006) [10] clarifies that the academic norms of the Spanish universities show as a majority two methods: the theoretical method and practical method, among which several types, in some cases, are distinguished: laboratory, field, and classroom. The theoretical method is the most common and should not be considered a highly recommended strategy for the promotion of independent student learning. The practical method has no definition to determine clearly what its characteristics are and simply indicates the number of students that must be taken as maximum or as a reference for the formation of groups.

These changes are of great help to homogenize the classes with other countries that do not have a theoretical tradition and who have spent many years applying a cognitive methodology which, "is a process involving the acquisition or reorganization of cognitive structures through which information is processed and stored" Good and Brophy (1996:165) [11], where the student is part of the process not as a mere spectator but engaging and carrying out modifications on the process as well as the outcome.

This model helps to develop skills and competencies that remained incomplete with the traditional model, because students motivated by their own learning, want to inquire, investigate, work individually and in groups, broadening their knowledge and thus reach the desired and expected outcome of acquiring knowledge. More specifically Valcárcel (2003) [12] points out some of the characteristics that must be developed by university faculty.

- Faculty should be aware and understand the different ways that a student can learn.

- They must know the correct methodologies to be able to respond to new challenges.

- They must have the knowledge, skills and attitude necessary to employ student assessments as a tool to promote learning.

- They must use the opportunities offered by the development of information and communications technology.

- And to master the techniques of tutoring, both onsite and remotely.

These small guidelines can change the traditional attitude of the faculty to make them aware of how students can and must learn and why they are teaching.

The university faculty must know, accept and learn a range of skills, Valcárcel (2003) [12], which has not been developed when exercising their profession. They are experts in their field, but do not have the cognitive skills based on knowledge of content and pedagogical aspects of the subject, allowing them to develop suitable training activities for their group of students. Nor do they have metacognitive skills which will help them be more reflective and self-critical with their teaching, to be able to review and improve it. Communicative competence is not one of the skills required to be a university professor but certainly of great importance in transmitting knowledge. One of the most important things in teaching is how and therefore the transfer of knowledge to the students. Finally, not to be forgotten is the management and social skills involving the efficient management of education in different contexts and motivation in promoting teamwork, student behavior and attitude towards work. (Zabalza 2003) [13].

During these years the Spanish university faculty have used the tools they had to adapt to this new way of working, some with more success and some with less success. Universities have provided teacher training courses but always on a voluntary basis, while academics from other countries, like in the case of England, have not changed their way of working, at least substantially. For this reason the study that has been done has been a comparison between a Spanish and an English university, to see the similarities and differences when it comes to work of the university faculty, and whether deficits, that were found during the implementation, have been resolved during this first promotion.

\section{Methodology}

\subsection{Research}

The research conducted is of a quasi-experimental character, of the analysis of the needs of university faculty in 
their psychopedagogic training and the use of the teaching methodology framed within the European Higher Education Area, which has seen significant methodological changes in the university, for which university faculty do not have enough tools to cope with a teaching method with an innovative curriculum that focuses on student work and not on the teacher as the sole issuer agent of the teaching-learning process.

There are numerous studies concerning the training of university faculty in global or general terms, however, in this study we have drawn a comparison on the incorporation of the new European teaching plans and how it has changed the way of working for faculty and students, between Spain and England. Since the teaching degree is one that contains more faculty trained in teaching methods and pedagogic studies it is easier to identify if the differences are due to tradition and way of working and whether that training is essential for all university faculty. The reason for choosing faculty that give classes within the degree of primary school teachers was due to similarities in the degrees in Spain and England, both structurally and in their future careers, it is to safeguard against a large number of independent variables. The choice was simple because all the faculty within the teaching degree, both in Bedford and Ceu UCH, were used. In order to gain the participation of the faculty two methods were used. First the director of each university department convened a meeting in which the research was explained along with the need for collaboration. Second, an email was sent to all faculty to officially request their participation. In a few individual cases the faculty, who did not attend the meeting or did not answer the email, were located over the phone and individual meetings. The target populations were faculty who teach in the degree of primary school teachers for the 2010-2014 class at Ceu Cardenal Herrera University in Elche, Spain and Bedfordshire University in England.

In selecting instruments to measure it is crucial to know that we want to measure and compare, for this the questionnaire CEMEDEPU (Assessment Questionnaire Variables “Modulating” Teaching Style in Higher Education was selected, to analyze the work of the university faculty (Appendix 1). This questionnaire identifies three broad areas in the teaching work, the model focused on teaching, the model focused on learning and finally teaching skills of effective faculty. This questionnaire was developed by Bernardo Gargallo López, Amparo Fernández March and Miguel Angel Jimenez in 2007 with the objective of assisting an investigation into the teaching models of university faculty to confirm their compliance with the requirements of the European Higher Education Area.

The total participants were 42 university faculty: 21 who teach in the degree of primary education at the University CEU Cardenal Herrera. From those, 8 have pedagogical training and 13 have no pedagogical training. 21 university faculty from the University of Bedfordshire, also teaching in the degree of primary education, all 21 have pedagogical training. The total sample was very high as the turnout was $99 \%$ of faculty who taught in the teaching qualifications during these years both in Spain and England.

To carry out this research two types of variables were taken into account; Independent variables (IV), which are the countries that have carried out the study, the University of Bedfordshire in England and the University CEU Cardenal Herrera in Spain, gender, the role of the faculty, the type of university, one being a private institution and the other a public institution, years of teaching experience, pedagogical training of the faculty, and the dependent variables (DV) derived from the questionnaire passed to the faculty, the Teaching Centered Model, the Learning Centered Model and finally Effective Teaching Skills of the Faculty (Table 2).

Table 2. Summary of research variables.

\begin{tabular}{lll}
\hline & Variables \\
\hline V1 & Country \\
V2 & University \\
Independent Variables & Gender \\
& V4 & Type private or public \\
V5 & Years of teaching experience \\
V6 & Pedagogical training \\
V7 & Teaching centered model \\
D8 & Learning centered model \\
V9 & Effective teaching skills of the faculty \\
\hline
\end{tabular}




\subsection{Instruments}

The instrument used is the CEMEDEPU to identify the teaching methodology university faculty use and which tools they consider indispensable in their teaching style.

Assessment Questionnaire Variables "Modulating” Teaching Style in Higher Education, to analyze the work of the university faculty (CEMEDEPU) Gargallo, Fernandez and Jimenez in (2007) [14].

The aim of this questionnaire is to address research on teaching models of university faculty to corroborate if they comply with the requirements of the European Higher Education Area, which should be centered on a model focused on the learning domain of teaching skills.

The first two scales are based on the underlying theoretical structure of the models and the third incorporates references of the teaching skills.

This questionnaire consists of three scales:

Model centered on teaching. It consists of 16 items of the 51 within the questionnaire. It is based on the theoretical structure; it evaluates the concept of knowledge, learning, education, the teacher's role in this model, teaching methodology, learning materials and assessment methodology consistent with a traditional concept. It aims to find the use of the different strategies used in universities regarding traditional teaching models.

Model centered on learning. It consists of 17 items. It evaluates the conception of knowledge, learning, teaching, learning materials and assessment methodology consistent with a constructive design and is intended to capture other teaching strategies and methodologies from the incorporation of the EHEA, where the faculty focuses less in knowledge, but in the process of learning, giving prominence to the student.

Model focused on assessing the teaching skills of an effective teacher. It consists of 18 items. It evaluates the planning, communication with students, the appropriate use of methodologies for the objectives, consistent evaluation and criterias. This block incorporates references to teaching skills, it is to learn the different skills that the university faculty has or generates when working effectively, many of which are subject to study.

The questionnaire takes the form of the Likert scales with five answer choices for each item, ranging from "strongly disagree" to "strongly agree". A total score is obtained in the teaching model of university faculty after adding the three scales.

The instrument was validated with a sample of 332 teachers of public universities from the city of Valencia (Spain), the University of Valencia/Estudi General (UVEG) and the Polytechnic University of Valencia (UPV). The confidence level of $95 \%$ and a maximum error of 5\%, the Cronbach's alpha coefficient for the first scale was $0.879,0.382$ for the second, and the third 0.839 .

A cross-cultural validation was also performed so that the questionnaire was valid in England.

\section{Results}

The analysis of the results was conducted by collecting data from the questionnaire and running them through the program SPSS Version 20. Realizing a descriptive analysis and conducting a comparative analysis of averages.

The results obtained from carrying out the questionnaire were as follows.

In Spain the faculty gave the highest mark, a 5, to all questions except numbers 2, 4, 10, 13, and 17. Between 1 and 5 faulty gave the highest mark to questions $1,2,3,4,5,6,7,8,9,10,11,12,13,14,15,16,17,18,29,30$, 31 and 49. Between 11 and 15 faculty, more than half the Spanish sample, gave the highest mark to questions 22, 23, 24, 26, 28, 32, 34, 35, 36, 37, 38, 39, 41, 42, 44, 46, 47 and 48. The best rated questions were number 42 chosen by 16 faculty and number 43 chosen by 18 faculty.

On the opposite side, the minimum mark, a 1, was given to questions 1,2,4,5, 9,10,11,12,13,14,15,16,29,30,31, 40, 48 and 49. Less than 5 faculties gave a 1 to questions $1,4,5,9,11,13,14,15,16,29,30,31,40,48$ and 49. The worst valued questions, given a 1 , were questions 10 and 12, by 6 faculty each.

In England, all questions received a mark of 5 except number 14. The maximum mark of 5 was assigned to questions $1,2,3,4,5,7,8,9,10,11,12,13,14,15,16,29$ and 31 by, at most, 5 faculty. Between 11 and 15 faculty gave a 5 to questions 20, 23, 24, 25, 33, 34, 35, 36, 37, 39, 40, 41, 45, 46, 47, 50 and 51 . The best rated questions were numbers 27 and 43 by 16 faculty and questions 22, 26, 42, and 44 by 17 faculty.

On the opposite side, the minimum mark, a 1 , was given to questions $1,2,3,4,5,9,10,11,12,13,14,15,16$, $18,20,21,22,23,24,25,26,27,29,31,32,33,35,36,37,38,39,42,44,46,47$ and 48 , although not by a large number of faculty. Less than 5 faculties gave a mark of 1 to questions $1,3,5,14,16,18,20,21,22,23,24,25$, 
26, 27, 29, 31, 32, 33, 35, 36, 37, 38, 39, 42, 44, 46, 47 and 48. Between 5 and 10 faculty gave a mark of 1 to questions $2,4,9,10,11,13$ and 15 . The worst valued question was 12 by a total of 13 faculty.

Once done the descriptive analysis shows that the university faculty from both Spain and England have the highest score on the skills of effective teaching, being in the English case ( $\bar{X}=80.43$ ) with a DT of 6.99, with the Spanish it is $(\bar{X}=78.90)$ and a DT of 5.99. The teacher-centered model is the lowest rated, although a small increase is seen in the Spanish model ( $\bar{X}=43.67)$, English model $(\bar{X}=42.86)$. In the model focused on learning the scores are similar, but increase slightly on the English model $(\bar{X}=72.38)$ being the DT 11.81 and the Spanish model ( $\bar{X}=69.57$ ) and a DT 7.58 (Table 3).

In the case of the data obtained by focusing on the teaching experience it is seen that in Spain most of the teachers have less than four years' experience with very similar experience between 4 and 10 years and experience between 10 and 20 years. It stands out that few teachers, at CEU Cardenal Herrera University, have more than 20 years' experience. While in the English case there are only teachers with teaching experience between 10 and 20 years and more than 20 years. In the model centered on the teacher, it can be observed that it is the only case in which the score is greater with the Spanish case. Being the Spanish ( $\bar{X}=43.67$ and DT 11.81) and in the English case ( $\bar{X}=42.86$ and DT 10.75). However, the average increases in both the English case centered teaching model ( $\bar{X}=72.38$ and DT 11.81), Spanish case ( $\bar{X}=69.57$ and DT 7.58) and effective teacher skills in England where the score is ( $\bar{X}=80.43$ and DT 14.12) and in Spain ( $\bar{X}=78.90$ and DT 5.99) (Table 4).

In the results from the testing of mean differences it is observed that none of the variables significantly improved, although there is was a big difference between the English case and the Spanish case in the Learning centered model, where in the Spanish case $(F(3)=0.38, p=0.77)$ and in the English case $(F(1)=0.76, p=0.39)$ and in the skills of being an effective teacher in the Spanish case $(F(3)=0.39, p=0.76)$ and the English case $(\mathrm{F}(1)=1.01, \mathrm{p}=0.33$ ) (Table 5).

Another aspect to be analyzed in the study of the differences between Spanish and English faculty is the pedagogical training they have.

The data concludes that in Spain some faculty have pedagogical training while others do not. While in England all faculty have pedagogical training. In the teacher-centered model the higher scores are for the Spanish teachers without pedagogical training, these being ( $\bar{X}=47.54$ and DT 11.29), and in England ( $\bar{X}=42.86$ and DT 10.76). In Spain, teachers with pedagogical training ( $\bar{X}=37.38$ and DT 10.35). In the learning focused model, English teachers with pedagogical training have the highest score ( $\bar{X}=73.38$ and DT 11.81), followed by Spanish teachers with pedagogical training ( $\bar{X}=71.63$ DT 6.89) and with the lowest score, the Spanish teachers without teacher pedagogical training ( $\bar{X}=68.31$ DT 7.97). It stands out that in effective skills of the faculty the Spanish faculty have some higher scores on faculty without pedagogical training (DT $=79.08$ and 5.06) with pedagogical training ( $\bar{X}=$ DT 7.65 and 78.63) but always surpassed by the English case (DT = 80.43 and 14.12) (Table 6).

In the study of mean differences it can be seen that the mean does not improve in the second variable (no pedagogical training), although in the case of learning centered model the following is obtained; P.04(F(1) $=4.34)$. Whereas in other models much more evident; Learning centered model $(F(1)=0.55, p=0.46)$ and Teaching skills of effective faculty $(F(1)=0.01, p=0.93)$ (Table 7).

\section{Discussion and Conclusion}

The article presented stems from some of the demands of the Bologna process and the changes at the university

Table 3. Descriptive analysis by country of the university faculty.

\begin{tabular}{cccccc}
\hline \multicolumn{1}{c}{ Variables } & Country & n & $\bar{X}$ & D.T \\
\hline Teaching centered model & Spain & 21 & 43.67 & 11.81 \\
& England & 21 & 42.86 & 10.76 & 7.58 \\
Learning centered model & Spain & 21 & 69.57 & 72.38 & 11.81 \\
& England & 21 & 78.90 & 5.99 \\
Effective teaching skills of the faculty & Spain & 21 & & \\
& England & 21 & 80.43 & 6.99 \\
\hline
\end{tabular}


Table 4. Descriptive analysis of the teaching centered model, the learning centered model, and effective teaching skills of the faculty depending on the years of teaching experience and country.

\begin{tabular}{|c|c|c|c|c|c|}
\hline Variables & Country & Years of teaching experience & $\mathbf{n}$ & $\bar{X}$ & D.T \\
\hline \multirow{15}{*}{ Teaching centered model } & \multirow{5}{*}{ Spain } & Less than 4 years & 8 & 46.88 & 16.06 \\
\hline & & Between 4 and 10 years & 5 & 45 & 8.94 \\
\hline & & Between 10 and 20 years & 6 & 39.50 & 7.94 \\
\hline & & More than 20 years & 2 & 40 & 11.31 \\
\hline & & Total & 21 & 43.67 & 11.81 \\
\hline & \multirow{5}{*}{ England } & Less than 4 years & 0 & - & - \\
\hline & & Between 4 and 10 years & 0 & - & - \\
\hline & & Between 10 and 20 years & 12 & 44.25 & 10.87 \\
\hline & & More than 20 years & 9 & 41 & 10.95 \\
\hline & & Total & 21 & 42.86 & 10.75 \\
\hline & \multirow{5}{*}{ Spain } & Less than 4 years & 8 & 68.63 & 6.09 \\
\hline & & Between 4 and 10 years & 5 & 68.20 & 11.67 \\
\hline & & Between 10 and 20 years & 6 & 72.50 & 7.26 \\
\hline & & More than 20 years & 2 & 68 & 2.83 \\
\hline & & Total & 21 & 69.57 & 7.58 \\
\hline \multirow[t]{9}{*}{ Learning centered model } & \multirow{5}{*}{ England } & Less than 4 years & 0 & - & - \\
\hline & & Between 4 and 10 years & 0 & - & - \\
\hline & & Between 10 and 20 years & 12 & 70.42 & 15.23 \\
\hline & & More than 20 years & 9 & 75 & 4.06 \\
\hline & & Total & 21 & 72.38 & 11.81 \\
\hline & & Less than 4 years & 8 & 78 & 6.28 \\
\hline & & Between 4 and 10 years & 5 & 79.60 & 5.03 \\
\hline & Spain & Between 10 and 20 years & 6 & 78.17 & 7.57 \\
\hline & & More than 20 years & 2 & 83 & 2.83 \\
\hline \multirow{6}{*}{ Effective teaching skills of the faculty } & & Total & 21 & 78.90 & 5.99 \\
\hline & \multirow{5}{*}{ England } & Less than 4 years & 0 & - & - \\
\hline & & Between 4 and 10 years & 0 & - & - \\
\hline & & Between 10 and 20 years & 12 & 77.75 & 17.90 \\
\hline & & More than 20 years & 9 & 84 & 5.70 \\
\hline & & Total & 21 & 80.43 & 14.12 \\
\hline
\end{tabular}

Table 5. Mean difference in faculty by country and years of teaching experience.

\begin{tabular}{|c|c|c|c|c|}
\hline Variables & Country & gl & $\mathbf{F}$ & Sig. \\
\hline \multirow{2}{*}{ Teaching centered model } & Spain & 3 & 0.49 & 0.69 \\
\hline & England & 1 & 0.46 & 0.51 \\
\hline \multirow{2}{*}{ Learning centered model } & Spain & 3 & 0.38 & 0.77 \\
\hline & England & 1 & 0.76 & 0.39 \\
\hline \multirow{2}{*}{ Effective teaching skills of the faculty } & Spain & 3 & 0.39 & 0.76 \\
\hline & England & 1 & 1.01 & 0.33 \\
\hline
\end{tabular}


Table 6. Descriptive analysis of the Teaching centered model, the Learning centered model, and Effective teaching skills of the faculty in Spain and England depending on the teaching experience, pedagogical training and no pedagogical training.

\begin{tabular}{|c|c|c|c|c|c|}
\hline Variables & Country & Formación & $\mathbf{n}$ & $\bar{X}$ & D.T \\
\hline \multirow{4}{*}{ Teaching centered model } & \multirow{2}{*}{ Spain } & Pedagogical training & 8 & 37.38 & 10.35 \\
\hline & & No Pedagogical training & 13 & 47.54 & 11.29 \\
\hline & \multirow{2}{*}{ England } & Pedagogical training & 21 & 42.86 & 10.76 \\
\hline & & No Pedagogical training & - & - & - \\
\hline \multirow{4}{*}{ Learning centered model } & \multirow{2}{*}{ Spain } & Pedagogical training & 8 & 71.63 & 6.89 \\
\hline & & No Pedagogical training & 13 & 68.31 & 7.97 \\
\hline & \multirow[t]{2}{*}{ England } & Pedagogical training & 21 & 73.38 & 11.81 \\
\hline & & No Pedagogical training & - & - & - \\
\hline \multirow{4}{*}{ Effective teaching skills of the faculty } & \multirow{2}{*}{ Spain } & Pedagogical training & 8 & 78.63 & 7.65 \\
\hline & & No Pedagogical training & 13 & 79.08 & 5.06 \\
\hline & \multirow{2}{*}{ England } & Pedagogical training & 21 & 80.43 & 14.12 \\
\hline & & No Pedagogical training & - & - & - \\
\hline
\end{tabular}

Table 7. Mean difference of university faculty by country depending on pedagogical training or not.

\begin{tabular}{ccccc}
\hline Variables & Country & gl & F & Sig. \\
\hline Teaching centered model & Pedagogical training No Pedagógica & 1 & 4.34 & 0.04 \\
Learning centered model & Pedagogical training No Pedagógica & 1 & 0.55 & 0.46 \\
Effective teaching skills of the faculty & Pedagogical training No Pedagógica & 1 & 0.01 & 0.93 \\
\hline
\end{tabular}

level, understanding said changes as a new style of teaching in which students are the center of the teachinglearning process and the teacher changes the role from speaker to guidance and support on autonomous learning of the student. This has been a considerable change in Spain, while in England the changes have been minor. Although the process has been more conscious and meticulous during these years in Spain, the results of the study open the door to the good work being done by university faculty.

It has been shown that the CEMEDEPU instrument has usefulness and applicability as an instrument designed to recognize communication, social skills, conflict resolution and the teaching process in Spain and England, helping to resolve existing doubts between the two countries on how they work at the University CEU Cardenal Herrera and University of Bedfordshire.

The data suggest that the Spanish faculty focuses more on the model focused on teaching, though not significantly, due to its high degree of theoretical teaching tradition, although it is not considered significant, so we can say that despite that tradition and working for years focused on lecturing and the teacher as the center of learning, thanks to the unification process of university education in Europe, Spain is, day by day, closer to focusing entirely on the model centered on learning.

It stands out that the English faculty focuses mostly on the learning focused model, with the center of attention being the university student and understanding the role of teaching as a guide for the student and collaborative work, so that students acquire significant and competent learning.

Pedagogical training in Spain is much lower than in England, where 100\% of the faculty had pedagogical training. It is very striking that despite being an education degree, 13 teachers of 21 in Spain did not have pedagogical training or related official training with regards to methodology. This data is consistent with the model focused on teaching, which shows that pedagogical training influences the decision making when planning and imparting a class and therefore the model and the concept of teaching. So, the less pedagogical training there is the more the classes are centered on the model focused on teaching. 
Another aspect that stands out is that, both in Spain and in England, the more pedagogical training, the greater the results focused on the skills of effective teacher model. Training and years of teaching experience help the faculty to be more effective and have greater skills when carrying out their teaching.

Finally, a remark on a non-significant detail due to the number of participants, but that points out, slightly, that in Spain, experience, the years that faculty have teaching classes, shows a methodology more focused on teaching, because of the university tradition. Whilst in England, the more experience faculty have, the more the faculty focus on the learning model.

\section{References}

[1] Blández Ángel, J., González Maura, V., López Rodríguez, A. and Sierra Zamorano, M.A. (2006) La formación de profesores responsables a través de la investigación-acción. Revista de investigación educativa, RIE, 24, 71-96. (Responsible Teacher Training through Action Research.)

[2] Pello Aramendi, J. (coord.) (2005) La incidencia de la convergencia europea de la educación superior y la nueva concepción de los créditos europeos (ECTS) en las estrategias de enseñanza-aprendizaje del profesorado universitario. P. Aramendi, San Sebastian. (The Incidence of European Convergence of Higher Education and the New Concept of European Credits (ECTS) in Teaching and Learning Strategies of University Teachers.)

[3] García Gallego, A. and Blanco Alonso, P. (2007) De La Sorbona a Londres: El camino hacia el Espacio Europeo de Educación Superior (adaptación en España: especial referencia a los Estudios Económico-Empresariales). Pecunia: Revista de la Facultad de Ciencias Económicas y Empresariales, 5, 107-144. (Sorbonne to London: The Path to the European Higher Education Area (Adaptation in Spain: Special Reference to the Economic and Business Studies))

[4] Vázquez Aguado, O. (2005) El espacio europeo de educación superior y el trabajo social en España. Portularia: Revista de Trabajo Social. Ejemplar dedicado a: La convergencia en los estudios de trabajo social, 5, 239-255. (The European Higher Education and Social Work in Spain)

[5] Bain, K. and Traducido por Barberá, O. (2006) Lo que hacen los mejores profesores de Universidad Valencia: Publicaciones de la universidad de Valencia. (What the Best University Faculty Do.)

[6] Valle Gálvez, J.A. (2006) El Espacio Europeo de Educación Superior, Planteamiento y perspectivas. Revista electrónica de estudios internacionales (REEI), 11. (The European Higher Education Area, Approach and Perspectives.)

[7] Molero López-Barajas, D. (2007) Rendimiento académico y opinión sobre la docencia del alumnado participante en experiencias piloto de implantación del Espacio Europeo de Educación Superior. Relieve: Revista Electrónica de Investigación y Evaluación Educativa, 13, 2. (Academic Performance and Opinion on Teaching Students Participating in Pilot Implementation of the European Higher Education Area Experiences.)

[8] Noguera Tur, J. (2004) Oportunidad, posibilidad e imposibilidad de las transformaciones que propone el proceso de Bolonia. Una experiencia desde la geografía. Transformaciones que propone el proceso de Bolonia. Cuadernos. de geografía. 76. (Opportunity, Possibility and Impossibility of the Changes Proposed by the Bologna Process. An Experience from Geography. Changes Proposed by the Bologna Process.)

[9] Mayer, R.E. (1992) Cognition and Instruction: On Their Historic Meeting within Educational Psychology. Journal of Educational Psychology, 84, 405-412. http://dx.doi.org/10.1037/0022-0663.84.4.405

[10] De Miguel, M. (Coord.) (2006) Metodologías de enseñanza y aprendizaje para el desarrollo de competencias. Orientaciones para el profesorado universitario ante el espacio euro $\neg$ peo de educación superior. Alianza, Madrid. (Teaching and Learning Methodologies for Skills Development. Guidelines for Faculty within the European Higher Education Area).

[11] Good, T. and Brophy, J. (1996) Psicología Educativa Contemporánea. McGraw-Hill, México. (Contemporary Educational Psychology.)

[12] Valcárcel (2003) La preparación del profesorado universitario español para la Convergencia Europea en Educación Superior. Proyecto EA2003-0040. (The preparation of Spanish University Teachers for European Convergence in Higher Education).

[13] Zabalza, M.A. (2003) Las competencias docentes del profesorado universitario: Calidad y desarrollo profesional. Madrid: Narcea. (Teaching Skills of University Teachers: Quality and Professional Development).

[14] Gargallo López, B., Suárez Rodríguez, J., Garfella Esteban, P.R. and Fernández March, A. (2011) El cuestionario CEMEDEPU un instrumento para la evaluación de la metodología docente y evaluativa de los profesores universitarios ESE: Estudios sobre educación $\mathrm{N}^{\circ}$. 21, 9-40. (Questionnaire CEMEDEPU, an Instrument for the Assessment of Teaching and Teaching Methodologies by University Faculty.) 


\section{A. R. López et al.}

\section{Appendix 1}

The questionnaire Evaluation of variables Modulating Style of Teaching in Higher Education. C.E.M.E.D.E.P.U

Authors: Bernardo Gallardo López, Amparo Fernández March y Miguel Ángel Jiménez Rodríguez.

Academic qualifications:

Workplace: $ـ \quad$ ( ) Public ( ) Private

Teaching experience (Years):

City, State, Country :
( ) Male
( ) Female
Date:

Cross your answer, please. Remember: 1 Strongly disagree, 2 disagree, 3 undecided, 4 Agree 5 Strongly Agree

\subsection{CENTERED ON TEACHING}

Numbers

Knowledge is established within the disciplines and it is the teachers who have the knowledge and have to teach the students.

It is sufficient for students to learn and understand the underpinning principles of the subject; they do not need to know more than that in their university studies.

3 Learning is to acquire knowledge and develop existing one.

The primary task of the university lecturer is to transmit knowledge to students.

5 The most important quality of being a good teacher is to master the subject being taught.

A good teacher is the one who explains their subject well.

My primary responsibility is to properly organise the knowledge that needs to be learned and to teach it in a comprehensible manner.

Time spent in theoretical lessons should be used to properly explain the contents of a subject properly.

9 In my theoretical classes the lecture is the fundamental methodology.

The basic role of students is to be attentive in class and take good notes.

Student interactions in class should mainly be to answer a teacher's questions or to ask any questions they may have.

12 The best method to assess students is through exams.

13 Exams should be limited to the assessment of acquired knowledge.

14 The purpose of exams is to assess students' learning and grade it.

15 Only the lecturer is qualified to assess students' learning. 
Cross your answer, please. Remember: 1 Strongly disagree, 2 disagree, 3 undecided, 4 Agree 5 Strongly Agree 1.2 MODEL CENTERED ON LEARNING

17 Knowledge is not something set in the subjects and included in manuals and other documents, but rather something developed between lecturer and student.

18 Knowledge must be constructed by students with the teacher's guidance.

19 Learning is personally constructing meaning.

20 I give students an opportunity to make personal contributions, such as asking them to predict results, propose hypotheses and confirm them, etc.

21 The knowledge that my students acquire serves them to interpret the reality which they live in, not just to pass the class.

22 I use my lessons as a learning environment that encourage active student learning (through the posing and solving of problems, promotion of student participation, establishing connections with reality).

23 I adopt a range of teaching approaches and adapt these to the needs of the students.

24 I systematically use questions in my lessons to help students develop their thinking.

25 I make use of case studies and/or simulations in the classroom to enhance the integration of theory and practice.

26 I conduct seminars with students in my course.

27 I use real life examples to demonstrate the theory taught.

28 I use the tutorial time within an established work plan to advise students and I do not limit this to those who have made appointments.

29 The use I make of new technologies encourages student engagement, e.g. through online mentoring, forums, etc.

30 My students must learn to fully self-assess their work and I help them to do so.

31 I use exams as a complementary method of evaluation along with other methods of teaching. (papers, essays, reports, portfolios, etc.)

32 I use different methods of formative assessment (e.g. questions in class, papers, reports, tests, essays, etc.) reviewing and returning students' work with suggestions on how to improve.

33 I evaluate not only to assess the results of the students, but also to get information of the learning process and make the necessary improvements.

\section{Cross your answer, please. Remember: 1 Strongly disagree, 2 disagree, 3 undecided, 4 Agree 5 Strongly Agree}

\subsection{THE TEACHING SKILLS OF AN EFFECTIVE TEACHER}

34 I plan my classes every school year, dedicating time to this task.

35 I provide my students with the course syllabus and explain it.

36 I share the learning outcomes for each session.

37 My students know which texts are essential reading.

38 I briefly review of what was discussed in the previous lesson.

39 At the end of lessons, I make summarise what we discussed.

40 I present content in a manner that excites the students' interest.

41 I aim to convey my own enthusiasm for the subject I teach to my students.

42 I try to make sure there is an atmosphere of good relationships in class.

43 I'm interested in my students as people.

44 I evaluate learning according to the objectives established in the planning.

45 I set clear success criteria for assessments and the students are well aware of these.

46 I inform my students of assessment methods I will be using.

47 My students know the criteria that I will use for marking the exams.

48 I perform an initial evaluation to determine the student's prior knowledge.

49 I carry out evaluations at different times of the course to keep track of student learning.

50 I take account of the results of the evaluations to modify my planning, teaching, and methodology in the short and/or medium term.

51 I offer guidance on how my students can improve their work. 